\title{
Prevalence and clinical features of celiac disease in patients with hepatitis B virus infection in Southern Brazil
}

\author{
Angélica Luciana Nau ${ }^{[1]}$, Leonardo Fayad ${ }^{[1]}$, César Lazzarotto ${ }^{[1]}$, \\ Maria Beatriz Cacese Shiozawa ${ }^{[2]}$, Esther Buzaglo Dantas-Corrêa ${ }^{[1]}$, \\ Leonardo de Lucca Schiavon ${ }^{[1]}$ and Janaína Luz Narciso-Schiavon ${ }^{[1]}$
}

[1]. Núcleo de Estudos em Gastroenterologia e Hepatologia, Universidade Federal de Santa Catarina, Florianópolis, SC. [2]. Departamento de Patologia, Universidade Federal de Santa Catarina, Florianópolis, SC.

\begin{abstract}
Introduction: Celiac disease is an autoimmune disorder that involves gluten intolerance and can be triggered by environmental factors including hepatitis B virus (HBV) infection. This study aimed to describe the prevalence of celiac disease in individuals with HBV infection and to describe the clinical and laboratory characteristics of celiac disease associated with HBV. Methods: This cross-sectional study included 50 hepatitis B patients tested for IgA anti-endomysial antibodies (EMAs) and tissue antitransglutaminase (TTG) between August 2011 and September 2012. Results: Fifty patients were included with a mean age of $46.0 \pm 12.6(46.0)$ years; $46 \%$ were female and $13 \%$ were $\mathrm{HBeAg}+$. Six patients had positive serology for celiac disease, four were EMA+, and five were TTG+. When individuals with positive serology for celiac disease were compared to those with negative serology, they demonstrated a higher prevalence of abdominal pain $(100 \%$ vs. $33.3 \%, p=0.008)$, lower median creatinine $(0.7 \mathrm{mg} / \mathrm{dL}$ vs. $0.9 \mathrm{mg} / \mathrm{dL}, \mathrm{p}=0.007)$ and lower mean albumin $(3.6 \pm 0.4 \mathrm{~g} / \mathrm{L}$ vs. $3.9 \pm 0.3 \mathrm{~g} / \mathrm{L}, \mathrm{p}=0.022)$. All individuals with positive serology for celiac disease underwent upper digestive endoscopy, and three of the patients exhibited a macroscopic pattern suggestive of celiac disease. Histologically, five patients demonstrated an intra-epithelial lymphocytic infiltrate level > $30 \%$, and four patients showed villous atrophy associated with crypt hyperplasia on duodenal biopsy. Conclusions: An increased prevalence of celiac disease was observed among hepatitis B patients. These patients were symptomatic and had significant laboratory abnormalities. These results indicate that active screening for celiac disease among HBV-infected adults is warranted.
\end{abstract}

Keywords: Hepatitis B virus. Hepatitis B. Celiac disease.

\section{INTRODUCTION}

Celiac disease $(\mathrm{CD})$ is an intolerance to gluten, a protein found in wheat, rye and barley. It is recognized as a chronic autoimmune disorder that occurs in genetically predisposed individuals, both children and adults ${ }^{1-3}$, and it affects approximately $1 \%$ of the world population ${ }^{4}$.

Celiac disease involves chronic inflammation of the gut mucosa from an inappropriate T-cell-mediated response to gluten ingestion ${ }^{1}$. A possible pathogenic mechanism involves increased permeability of the intestinal epithelium to gliadin (the immunogenic component of gluten) caused by dysregulation of the innate and adaptive immune systems ${ }^{5}$. Intestinal cluster of differenciation antigen 4 (CD4) T cells interact with gliadin peptides presented by human leukocyte antigens (HLA)-DQ2

Address to: Dr ${ }^{\mathrm{a}}$ Janaína Luz Narciso-Schiavon. Dept ${ }^{\circ}$ Clínica Médica/HU Polydoro Ernani de São Thiago/UFSC. Rua Professora Maria Flora Pausewang $\mathrm{s} / \mathrm{n}^{\circ}, 3^{\circ}$ andar, Trindade, 88040-900 Florianópolis, SC, Brasil.

Phone: 5548 3721-9014

e-mail: janaina.narciso@uol.com.br

Received 3 May 2013

Accepted 11 July 2013 or DQ8 and produce interferon-gamma, which leads to mucosal inflammation and structural and functional damage ${ }^{1,3}$.

The correlation between celiac disease and environmental factors other than gluten is not completely understood. Breastfeeding, smoking and viral infections may contribute to the disease onset ${ }^{1}$. Cross-reactivity has been proposed as a source of autoimmunity ${ }^{6}$, and several studies have demonstrated a relationship between adenovirus, rotavirus, enterovirus and hepatitis $\mathrm{C}$ virus infection and the development of celiac disease ${ }^{2,6}$. Hepatitis B virus (HBV) infection leads to the activation of several immune system components that has been suggested to culminate in the production and release of interferon and interleukins that disrupt the intestinal mucosal barrier, allowing the penetration of immunogenic peptides and activation of CD4 T lymphocytes. There appears to be an increase in the production of HLA-DQ8, which links gluten peptide molecules and facilitates activation of other immune cells. It is suggested that HBV can trigger the pathophysiological processes that lead to mucosal inflammation induced by gluten ${ }^{6}$. However, concrete data regarding the association of celiac disease and HBV are not available, although two billion people in the world have been infected by this virus ${ }^{6,7}$. The highest prevalence rates are found in Eastern Europe and countries with European colonization ${ }^{8}$.

Because of the large number of European descendants in Santa Catarina, southern Brazil, a high prevalence of celiac 
disease is expected. Because the relationship between HBV and celiac disease has yet to be established, this study aimed to describe the prevalence of celiac disease in individuals with chronic HBV infection and to describe their clinical and laboratory characteristics.

\section{METHODS}

This descriptive case series study included consecutive hepatitis B surface antigen (HBsAg)-positive adult patients who presented at the Gastroenterology and Hepatology Outpatient Clinic at our institution between August 2011 and September 2012 and underwent celiac disease screening for anti-endomysial (EMA) and anti-transglutaminase (TTG) antibodies. The study subjects gave written informed consent. Patients with incomplete clinical and laboratory data registration in their medical records were excluded from the study.

Clinical, laboratory and histological findings were collected from data contained in the medical records. The patients were analyzed according to the following clinical and demographic characteristics: sex, race, age, comorbidities (diabetes mellitus, dyslipidemia and hypertension) and the presence of diarrhea or abdominal pain. The laboratory variables analyzed were: hepatitis $\mathrm{B} e$ antigen ( $\mathrm{HBeAg}$ ), hepatitis $B$ virus-deoxyribonucleic acid (HBV-DNA), creatinine, hemoglobin, platelets, ferritin, transferrin saturation, aspartate aminotransferase (AST), alanine aminotransferase (ALT), alkaline phosphatase (ALP), gamma-glutamyltransferase (GGT), direct bilirubin, albumin and prothrombin activity. The biochemical tests were expressed as absolute values. The immunoglobulin A (IgA) TTG and IgA EMA serological tests were used for celiac disease screening ${ }^{1,3}$. EMA was detected by indirect immunofluorescence, and TTG was detected using a commercial enzyme linked immunosorbent assay (ELISA). Patients with either EMA- or TTG-reactive antibodies were considered to have positive serology for celiac disease. Total serum IgA was quantified in patients negative for both EMA and TTG to exclude the presence of a selective IgA deficiency.

Upper digestive endoscopy and duodenal biopsy were indicated for individuals with positive serology for celiac disease. Duodenal fragments were fixed in $10 \%$ formalin, processed with paraffin and stained with hematoxylin and eosin (HE). For diagnoses of celiac disease, the following histological variables were analyzed: lymphocytic infiltrate, villous atrophy and crypt hyperplasia.

The continuous variables were compared using Student's $t$ test or the Mann-Whitney test when appropriate. The categorical variables were compared using the chi-square test or Fisher's exact test to identify characteristics associated with the positivity of celiac disease antibodies in individuals with hepatitis B. All of the tests were two-tailed and conducted using the statistical software Statistical Package for the Social Sciences (SPSS) version 17.0 (SPSS; Chicago; Illinois; USA).

\section{Ethical considerations}

The study protocol conformed to the ethical guidelines of the 1975 Helsinki Declaration and was approved by the review board of the Universidade Federal de Santa Catarina as Study Number 131.513.

\section{RESULTS}

\section{Patient characteristics}

From August 2011 to September 2012, 112 HBV-infected patients were considered for study enrollment, and sixty-two individuals were excluded from the study because they were not tested for EMAs or TTG antibodies.

The characteristics of the 50 consecutive patients fulfilling the inclusion criteria are summarized in Table 1 . The mean age was $46.0 \pm 12.6$ years, $46 \%$ of the patients were female and $13 \%$ of the patients were HBeAg-positive. Regarding the laboratory characteristics, the mean \pm standard deviation (median) values for ALT, albumin, prothrombin activity and platelet count levels were, respectively, $51.8 \pm 39.2(41.0) \mathrm{U} / \mathrm{L}, 3.9 \pm 0.4(3.9) \mathrm{g} / \mathrm{dL}, 81.9 \%$ $\pm 14.8 \%(77.9 \%)$ and $197,580.0 \pm 70,495.1(188,000.0) / \mathrm{mm}^{3}$.

\section{Factors associated with positive serology for celiac disease}

When compared to other patients, the patients with positive serology for celiac disease presented a higher prevalence of abdominal pain $(100 \%$ vs. $33.3 \%, \mathrm{p}=0.008)$, a lower median creatinine concentration $(0.7 \mathrm{mg} / \mathrm{dL}$ vs. $0.9 \mathrm{mg} / \mathrm{dL}, \mathrm{p}=0.007)$ and a lower mean albumin concentration $(3.6 \pm 0.4 \mathrm{~g} / \mathrm{dL}$ vs. 3.9 $\pm 0.3 \mathrm{~g} / \mathrm{dL}, \mathrm{p}=0.022)$. The median hemoglobin level tended to decrease $(12.8 \mathrm{~g} / \mathrm{dL}$ vs. $14.7 \mathrm{~g} / \mathrm{dL}, \mathrm{p}=0.088)$ and the proportion of patients reporting diarrhea tended to be higher $(40 \%$ vs. $5.6 \%$, $\mathrm{p}=0.066$ ) among the celiac disease patients. No differences were observed regarding age; presence of diabetes mellitus, dyslipidemia or hypertension; platelet count; ferritin; transferrin saturation; prothrombin activity; or levels of ALT, AST, GGT, ALP, direct bilirubin or HBV-DNA.

\section{Characteristics of individuals with positive serology for celiac disease}

Six $(12 \%)$ of the 50 patients had positive serology for celiac disease; four $(66.7 \%)$ of the six patients were EMA-positive, and five $(83.3 \%)$ of the patients were TTG-positive. Three individuals were reactive for EMA and TTG antibodies, two were reactive for TTG, and one was reactive solely for EMA. All six individuals underwent upper digestive endoscopy, and three $(50 \%)$ exhibited a macroscopic pattern suggestive of celiac disease. A duodenal histological evaluation demonstrated no significant alterations in one patient. Five (83.3\%) subjects presented with intra-epithelial lymphocytic infiltration of at least $30 \%$, and four $(66.7 \%)$ patients exhibited villous atrophy and crypt hyperplasia (Figure 1).

The clinical, laboratory and histological characteristics of individuals with positive serology for celiac disease are described in Table 2. All six patients had abdominal pain, whereas diarrhea was reported in $40 \%$ of the cases, and no patients exhibited anemia. None of the patients were positive for $\mathrm{HBeAg}$, but all presented HBV-DNA titers greater than or equal to $20,000 I \mathrm{I} / \mathrm{mL}$. 
TABLE 1 - Clinical and laboratorial characteristics of 50 patients with hepatitis B infection according to the presence of celiac disease antibodies: anti-endomysial and anti-transglutaminase.

\begin{tabular}{|c|c|c|c|c|}
\hline & & $\mathrm{CD}(+)$ & $\mathrm{CD}(-)$ & \\
\hline Characteristics & Total & $\mathrm{n}=6$ & $\mathrm{n}=44$ & $\mathrm{p}$ \\
\hline Age (years)* & $46.0 \pm 12.6$ & $44.3 \pm 9.0$ & $46.3 \pm 13.1$ & $0.728^{t}$ \\
\hline Female sex (\%) & 46.0 & 83.3 & 40.9 & $0.082^{\mathrm{f}}$ \\
\hline HBeAg $(\%) \dagger$ & 13.0 & 0.0 & 14.6 & $1.000^{\mathrm{f}}$ \\
\hline HBV-DNA $\geq 20.000 \mathrm{U} / \mathrm{mL}(\%)$ & 53.1 & 100.0 & 48.3 & $0.229^{\mathrm{f}}$ \\
\hline Diabetes mellitus (\%) & 10.0 & 0.0 & 11.4 & $1.000^{\mathrm{f}}$ \\
\hline Dyslipidemia (\%) & 5.0 & 0.0 & 5.7 & $1.000^{\mathrm{f}}$ \\
\hline Hypertension (\%) & 17.1 & 0.0 & 19.4 & $0.567^{\mathrm{f}}$ \\
\hline Diarrhea (\%) & 9.8 & 40.0 & 5.6 & $0.066^{\mathrm{f}}$ \\
\hline Abdominal pain (\%) & 41.5 & 100.0 & 33.3 & $0.008^{\mathrm{f}}$ \\
\hline Creatinine $(\mathrm{mg} / \mathrm{dL}) \S$ & $0.9 \pm 0.1$ & $0.7 \pm 0.1$ & $0.9 \pm 0.1$ & $0.007^{\mathrm{m}}$ \\
\hline Hemoglobin $(\mathrm{g} / \mathrm{dL}) \S$ & $14.5 \pm 0.9$ & $12.8 \pm 0.3$ & $14.7 \pm 1.0$ & $0.088^{\mathrm{m}}$ \\
\hline Platelets $\left(\mathrm{mm}^{3}\right) \S$ & $188,000 \pm 42,500$ & $245,500 \pm 94,500$ & $188,000 \pm 39,500$ & $0.204^{\mathrm{m}}$ \\
\hline Ferritin $(\mathrm{ng} / \mathrm{mL}) \S$ & $132.0 \pm 112.0$ & $65.7 \pm 48.7$ & $140.0 \pm 113.1$ & $0.457^{\mathrm{m}}$ \\
\hline Transferrin saturation (\%)* & $32.4 \pm 14.7$ & $27.3 \pm 17.6$ & $33.5 \pm 14.1$ & $0.352^{\mathrm{t}}$ \\
\hline AST (xULN)* & $33.7 \pm 19.7$ & $55.8 \pm 38.6$ & $30.6 \pm 13.9$ & $0.165^{\mathrm{t}}$ \\
\hline ALT $(x U L N) \S$ & $41.0 \pm 9.0$ & $39.0 \pm 11.5$ & $41.0 \pm 9.0$ & $0.927^{\mathrm{m}}$ \\
\hline $\operatorname{ALP}(x U L N) \S$ & $85.0 \pm 15.0$ & $87.0 \pm 15.0$ & $85.0 \pm 17.5$ & $0.988^{\mathrm{m}}$ \\
\hline GGT $(x U L N) \S$ & $28.0 \pm 7.0$ & $27.5 \pm 6.5$ & $28.0 \pm 7.0$ & $0.473^{\mathrm{m}}$ \\
\hline Direct bilirubin $(\mathrm{mg} / \mathrm{dL}) \S$ & $0.1 \pm 0.0$ & $0.1 \pm 0.0$ & $0.1 \pm 0.0$ & $0.378^{\mathrm{m}}$ \\
\hline Albumin $(\mathrm{g} / \mathrm{dL})^{*}$ & $3.9 \pm 0.4$ & $3.6 \pm 0.4$ & $3.9 \pm 0.3$ & $0.022^{\mathrm{t}}$ \\
\hline Prothrombin activity $(\%)^{*}$ & $81.9 \pm 14.8$ & $77.1 \pm 14.9$ & $82.6 \pm 14.8$ & $0.409^{\mathrm{t}}$ \\
\hline
\end{tabular}

CD: celiac disease; HBeAg: hepatitis B e antigen; HBV-DNA: hepatitis B virus-deoxyribonucleic acid; xULN: times upper limit of normal; AST: aspartate aminotransferase; ALT: alanine aminotransferase; ALP: alkaline phosphatase; GGT: gamma-glutamyltransferase; *mean \pm standard deviation; †available in 46 patients; łavailable in 32 patients. §: median \pm median absolute deviation; 'Student’s t-test; fFisher’s exact test; ${ }^{\mathrm{m}}$ Mann-Whitney test.

\section{DISCUSSION}

In Brazil, 16,775 cases of hepatitis B were reported in the year $2011^{9}$, but the actual number of cases is not completely known; there have been few studies, and Brazil has a poor notification system and a large geographic area ${ }^{10}$. In the State of Santa Catarina, the described seroprevalence of HBsAg is $0.7 \%$ to $1.2 \%$ among blood donors in Florianopolis ${ }^{11-13}$. The prevalence of HBsAg-positive individuals in Western Santa Catarina is $1.63 \%$, which is higher than that described in the northern and Southern regions of the state $(1.12 \%$ and $0.91 \%$, respectively) $)^{12}$.

The mean age of the HBV carriers varies between 38 and 52 years in the literature, which is similar to that described in this study ${ }^{14,15}$. Most affected individuals are male, with a prevalence of $52 \%$ to $61 \%$ in the United States ${ }^{16-18}, 86.6 \%$ in $\mathrm{China}^{19}$ and $41.8 \%$ to $76.1 \%$ in Brazil ${ }^{10,20,21}$, where males are 1.3 fold more likely to be infected with HBV than females ${ }^{22}$. In this study, $54 \%$ of the HBV carriers were male, which is similar to the rate described in the literature.

The prevalence of markers of viral replication varies among different populations. Following an evaluation of serum HBVDNA, the prevalence of undetectable levels of HBV-DNA $(<20 \mathrm{IU} / \mathrm{mL})$ was $46.6 \%$ among immigrants in Italy ${ }^{23}, 21.7 \%$ among pregnant women in Amazonas ${ }^{24}$ and $32 \%$ in São Paulo ${ }^{25}$. In a study by Kiesslich et al. ${ }^{24}$, quantitative analysis of HBV-DNA showed that $73.9 \%$ of pregnant women had levels lower than $200 \mathrm{IU} / \mathrm{mL}$, $14.4 \%$ had levels between 200 and $20,000 \mathrm{IU} / \mathrm{mL}$ and $8.7 \%$ had levels higher than $20,000 \mathrm{IU} / \mathrm{mL}^{24}$. Palumbo et al. ${ }^{23}$, found that $53.4 \%$ of patients had HBV-DNA levels between 4,600 and $260,000 \mathrm{IU} / \mathrm{mL}^{23}$. In São Paulo, 27\% of patients had HBV-DNA levels higher than $2,000 \mathrm{IU} / \mathrm{mL}$, and $9 \%$ had HBV-DNA levels higher than $20,000 \mathrm{IU} / \mathrm{mL}^{25}$. A study that included four of the five Brazilian regions (the South, Southeast, Midwest and Northeast) found undetectable HBV-DNA levels in $21.6 \%$ of patients, 


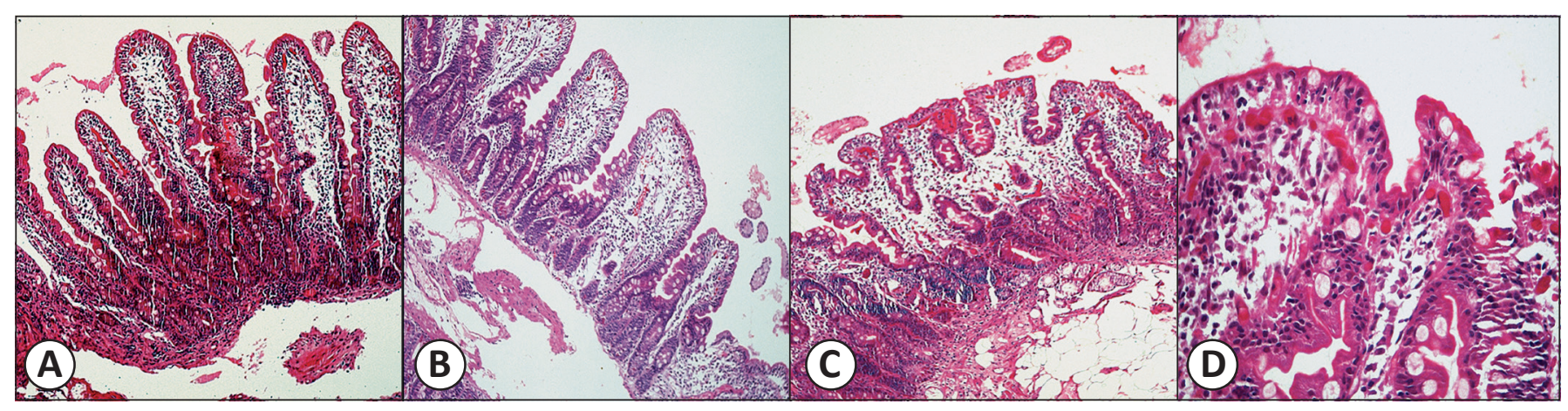

FIGURE 1 - A second duodenal portion biopsy showing mucosa with normal histological pattern (A) and biopsy showing the suggested histological changes of celiac disease (B, C, D). A: Duodenal mucosa showing conserved architecture with long parallel fingerlike villi (hematoxylin-eosin, HE; 100x); B: Duodenal mucosa showing slight villous shortening with crypt hyperplasia (HE 100x). C: Duodenal mucosa showing inflammatory changes and intense structural villous shortening (HE 100x); D: Details of the duodenal mucosa with many plasma cells and congestion in the lamina propria; intraepithelial lymphocytosis (HE 400x).

TABLE 2 - Clinical and laboratory characteristics of six individuals with hepatitis B infection and positive serology for celiac disease ( $\mathrm{n}=6$ ).

\begin{tabular}{|c|c|c|c|c|c|c|}
\hline & Case 1 & Case 2 & Case 3 & Case 4 & Case 5 & Case 6 \\
\hline Sex & $\mathrm{F}$ & $\mathrm{F}$ & M & $\mathrm{F}$ & $\mathrm{F}$ & $\mathrm{F}$ \\
\hline Caucasian & $\mathrm{Y}$ & $\mathrm{Y}$ & $\mathrm{Y}$ & $\mathrm{Y}$ & $\mathrm{Y}$ & $\mathrm{Y}$ \\
\hline Diarrhea & $\mathrm{N}$ & $\mathrm{N}$ & $\mathrm{Y}$ & $\mathrm{N}$ & $*$ & $\mathrm{Y}$ \\
\hline $\mathrm{HBeAg}$ & $(-)$ & $*$ & $(-)$ & $(-)$ & $(-)$ & $(-)$ \\
\hline $\mathrm{HBV}-\mathrm{DNA} \geq 20.000 \mathrm{UI} / \mathrm{ml}$ & $*$ & $*$ & $\mathrm{Y}$ & $\mathrm{Y}$ & $*$ & $\mathrm{Y}$ \\
\hline Hemoglobin (g/dL) & 13.0 & 12.5 & 17.2 & 11.5 & 12.4 & 13.9 \\
\hline Albumin (g/dL) & 3.5 & 3.87 & 3.8 & 3.0 & 3.3 & 3.9 \\
\hline UDE with biopsy & $\mathrm{Y}$ & $\mathrm{Y}$ & $\mathrm{Y}$ & $\mathrm{Y}$ & $\mathrm{Y}$ & $\mathrm{Y}$ \\
\hline villous atrophy & $\mathrm{N}$ & $\mathrm{Y}$ & $\mathrm{Y}$ & $\mathrm{N}$ & $\mathrm{Y}$ & $\mathrm{Y}$ \\
\hline crypt hyperplasia & $\mathrm{N}$ & $\mathrm{Y}$ & $\mathrm{Y}$ & $\mathrm{N}$ & $\mathrm{Y}$ & $\mathrm{Y}$ \\
\hline lymphocytic infiltration & $\mathrm{Y}$ & $\mathrm{Y}$ & $\mathrm{Y}$ & $\mathrm{N}$ & $\mathrm{Y}$ & $\mathrm{Y}$ \\
\hline
\end{tabular}

HBeAg: hepatitis B $e$ antigen; HBV-DNA: hepatitis B virus-deoxyribonucleic acid; F: female; M: male; *result not available; Y: yes; N: no; (+): positive; (-): negative; UDE: upper digestive endoscopy.

HBV-DNA levels lower than $2,000 \mathrm{IU} / \mathrm{mL}$ in $45.9 \%$ of patients, HBV-DNA levels between 2,000 and $20,000 \mathrm{IU} / \mathrm{mL}$ in $12.6 \%$ of patients and HBV-DNA levels higher than $20,000 \mathrm{IU} / \mathrm{mL}$ in $19.8 \%$ of patients ${ }^{26}$. HBeAg was found in $14.3 \%$ of patients with chronic hepatitis B in Turquia ${ }^{27}, 19.6 \%$ in China $^{28}, 30 \%$ in Campinas in southeastern Brazil ${ }^{29}$ and $37.3 \%$ in Rio Grande do Sul in southern Brazil ${ }^{30}$. The prevalence of $\mathrm{HBeAg}$-positive patients in this study was slightly lower than that found in the literature, but the prevalence of high levels of HBV-DNA was higher than that previously described. This inconsistency can be explained by the presence of $\mathrm{HBV}$ precore mutations, which alter the expression of $\mathrm{HBeAg}$, with viral replication in $\mathrm{HBeAg}$ negative patients and/or HBeAg-positive patients. In the State of Santa Catarina, HBV genotype D is common. This genotype is also found in Europe, particularly in the Mediterranean region, and it has a high rate of precore mutations $\mathrm{s}^{20,31}$. This finding could reflect the European immigration profile in southern Brazil ${ }^{32}$.

Celiac disease affects approximately $1 \%$ of most populations ${ }^{4}$, but in Sweden, it has been reported in 3\% of children of approximately 12 years of age ${ }^{5}$. In the United States, celiac disease affects one in every $120-300$ people $^{8}$. There are few studies regarding the prevalence of celiac disease in the general 
population of the Americas, and almost none of these studies have included intestinal biopsies to confirm the diagnosis ${ }^{33}$. Serological screening studies conducted in Brazil have shown a positivity rate of $0.15 \%$ to $1.7 \% \%^{34-36}$. In Curitiba, Paraná, the prevalence was one in 417 blood donors ${ }^{32}$. In Brasília, among 2,045 evaluated blood donors, 62 were positive for anti-gliadin (AGA) IgG and two were EMA-positive; only three individuals exhibited histological features of celiac disease ${ }^{33}$. A similar study conducted in São Paulo evaluated 4,000 serum samples from blood donors, and 24 showed positive serology: 11 were TTG- and EMA-positive, 10 were only TTG-positive and three were only EMA positive. Among the 21 patients who underwent duodenal biopsy, six (29\%) patients had some histological abnormality ${ }^{37}$.

Celiac disease classically presents with diarrhea (37.2\% to $91.3 \%$ ), abdominal pain ( $71 \%$ ) and anemia (3\% to $50.3 \%)^{3,38}$. This study contained patients with clinical complaints, which is unusual for a seroprevalence study but has been described by other authors ${ }^{32,37}$. All patients reported abdominal pain $(100 \%, p=0.008)$, whereas only $40 \%$ complained of diarrhea, which is the classic symptom of the disease ${ }^{1}$. Although anemia secondary to iron, vitamin B12 or folic acid deficiency is a typical symptom of celiac disease, it was not identified in any patients. Hemoglobin levels tended to be lower among individuals with celiac disease, but no significant changes in iron stores were observed.

The albumin level was lower in patients with celiac disease, which may have been secondary to the malabsorption that occurs in the disease and can lead to malnutrition ${ }^{39}$. This study found lower values of creatinine in patients with celiac disease compared to the other patients. The few studies that have described the renal function of patients with celiac disease have shown impaired renal function in these patients ${ }^{40}$. Most patients with positive serology for celiac disease in this study were female, and it is already known that females have lower creatinine levels than males because of the characteristic body mass of each sex. Renal function in patients with HBV and celiac disease must be further investigated in subsequent studies with a larger number of patients.

The literature that addresses the relationship between celiac disease and hepatitis B is limited; only three studies are available in PubMed, and none are from Brazil. Sima et al. ${ }^{41}$ performed serologic screening for celiac disease with EMA, TTG and AGA (IgA and IgG) in patients with chronic hepatitis B. The serologic screening was followed by duodenal biopsy in patients positive for EMA and/or TTG. The results demonstrated a prevalence of $10 \%$ for AGA IgA, $28 \%$ for AGA IgG, 3\% for EMA and $9 \%$ for $\mathrm{TTG}^{41}$. Iglesias et al. ${ }^{6}$ reported two patients who received the diagnosis of celiac disease following an acute hepatitis B infection ${ }^{7}$. Recently, Leonardi et al. ${ }^{7}$ evaluated the prevalence of positive serology for celiac disease in 60 patients who had an $\mathrm{HBV}$ infection during childhood; none of the patients tested were positive for EMA or TTG, and seven patients were positive for AGA, despite having no symptoms of celiac disease. The authors considered the anti-gliadin antibodies to have a low sensitivity and specificity for the diagnosis of celiac disease, and duodenal biopsy was not performed in any of the seven patients with positive serology ${ }^{7}$. Some studies have reported a lower efficacy of the vaccine against HBV in patients with celiac disease ${ }^{42-44}$. Although celiac disease is considered an autoimmune disorder and not an immunosuppressive condition, the lower efficacy of the vaccine may reflect a specific immunodeficiency in the development of anti-HBs antibodies and mechanisms of viral clearance. It is possible that individuals with celiac disease have a higher risk of chronic HBV infection compared to the general population. The association between celiac disease and hepatitis $\mathrm{B}$, although not well understood, justifies further investigation.

Although there are no previous data concerning the prevalence of celiac disease in the State of Santa Catarina, Brazil, this study found a higher prevalence of celiac disease in patients with $\mathrm{HBV}$ when compared to other populations in our country and around the world. The prevalence of celiac disease confirmed by biopsy was high among the HBsAgpositive patients, and these individuals were symptomatic and had significant laboratory abnormalities. Subjects with chronic HBV infection should be screened for celiac disease, including screening for the EMA and TTG antibodies, because the early diagnosis and treatment of the disease may prevent systemic complications and mortality ${ }^{5,41,45}$.

\section{ACKNOWLEDGMENTS}

Paper presented as a requirement for obtaining the Medical Doctor (MD) degree from Universidade Federal de Santa Catarina.

\section{CONFLICT OF INTEREST}

The authors declare that there is no conflict of interest.

\section{REFERENCES}

1. Green PHR, Jabri B. Coeliac disease. Lancet 2003; 362:383-391.

2. Plot L, Amital H. Infectious associations of celiac disease. Autoimmun Rev 2009; 8:316-319.

3. Rostom A, Murray JA, Kagnoff MF. American Gastroenterological Association (AGA) Institute technical review on the diagnosis and management of celiac disease. Gastroenterology 2006; 131:1981-2002.

4. Brandt KG, Silva GAP. Seroprevalence of celiac disease at a general pediatric outpatient clinic. Arq Gastroenterol 2008; 45:239-242.

5. Rubio-Tapia A, Murray JA. Celiac disease. Curr Opin Gastroenterol 2010; 26: 116-122.

6. Iglesias SS, Rodríguez SV, Rocha JLU, Arias RB, Saá WD, Antoranz JB, et al. Onset of celiac disease after acute hepatitis B infection. Gastroenterol Hepatol 2010; 33:17-20.

7. Leonardi S, La Rosa M. Are hepatitis B virus and celiac disease linked? Hepat Mon 2010; 10:173-175.

8. Farrell RJ, Kelly CP. Celiac sprue. N Engl J Med 2002; 346:180-188.

9. Sistema de Informação de Agravos de Notificação (SINAN). [Internet]. Brasília: Ministério da Saúde; 2004. [Cited 2012 October 11]. Available at: 
http://tr2004.saude.gov.br/sinanweb/tabnet/tabnet?sinannet/hepatitesvirais/ bases/hepabrnet.def.

10. Chávez JH, Campana SG, Haas P. An overview of hepatitis B in Brazil and in the state of Santa Catarina. Rev Panam Salud Publica 2003; 14:91-96.

11. Pereira LMMB, Martelli CMT, Merchán-Hamann E, Montarroyos UR, Braga MC, Lima MLC, et al. Population-based multicentric survey of hepatitis B infection and risk factor differences among three regions in Brazil. Am J Trop Med Hyg 2009; 8:240-247.

12. Hatzakis A, Wait S, Bruix J, Buti M, Carballo M, Cavaleri M, et al. The state of hepatitis B and C in Europe: report from the hepatitis B and C summit conference. J Viral Hepat 2011; 18:1-16.

13. Tonial GC, Passos AM, Livramento A, Scaraveli NG, Batschauer APB, Bueno EC, et al. Hepatits B marker seroprevalence and vaccination coverage in adolescents in the City of Itajaí, State of Santa Catarina, southern Brazil, in 2008. Rev Soc Bras Med Trop 2011; 44:416-419.

14. Rosini N, Mousse D, Spada C, Treitinger Al. Seroprevalence of HBsAg, anti-HBc and anti-HCV in southern Brazil, 1999-2001. Braz J Infect Dis 2003; 7:262-267.

15. Treitinger A, Spada C, Ferreira LA, Neto MS, Reis M, Verdi JC, et al. Hepatitis B and hepatitis C prevalence among blood donors and HIV-1 infected patients in Florianópolis, Brazil. Braz J Infect Dis 2000; 4:192196.

16. McGibbon E, Amoroso E, Baptiste-Norville A, Balter S, Baumgartner J, Bodenheimer A, et al. Surveillance for Chronic Hepatitis B Virus Infection - New York City, June 2008-November 2009. MMWR 2012; 6:6-9.

17. Zhou JY, Zhang L, Li L, Gu GY, Zhou Yi-Hua, Chen JH. High hepatitis $\mathrm{B}$ virus load is associated with hepatocellular carcinomas development in Chinese chronic hepatitis B patients: a case control study. Virol J 2012; 9:16.

18. Mbaye PS, Sarr A, Sire JM, Evra ML, Ba A, Daveiga J, et al. Liver stiffness measurement and biochemical markers in Senegalese chronic hepatitis B patients with normal ALT and high viral load. Plos One 2011; 6:1-7.

19. Huang S, Shallow S, Stier D, Shiono P, Nishimura A, Bihl I, et al. Characteristics of persons with chronic hepatitis B - San Francisco, California, 2006. MMWR 2007; 56:446-448.

20. Moorman AC, Gordon SC, Rupp LB, Spradling PR, Teshale EH, Lu M, et al. Baseline characteristics and mortality among people in care for chronic viral hepatitis: the chronic hepatitis cohort study. Clin Infect Dis 2013; 56:40-50.

21. Silva LC, Nova ML, Ono-Nita SK, Pinho JR, Sitnik R, Santos VA. Simultaneous quantitation of serum HBV DNA and $\mathrm{HBeAg}$ can distinguish between slow and fast viral responses to antiviral therapy in patients with chronic hepatitis B. Rev Inst Med Trop 2009; 51:261-268.

22. Silveira TR, Fonseca JC, Rivera L, Fav OH, Tapia R, Santos JI, et al. Hepatitis B seroprevalence in Latin America. Rev Panam Salud Publica 1999; 6:378-383.

23. Palumbo E, Scotto G, Faleo G, Cibelli DC, Saracino A, Angarano G. Prevalence of HBV genotypes in immigrants affected by HBV related chronic active hepatitis. Arq Gastroenterol 2007; 44:54-57.

24. Kiesslich D, Fraiji NA, Crispim MA, Pereira FR, Martinho AC, Campello $\mathrm{SC}$, et al. Prevalence of serologic and molecular markers of hepatitis B virus infection among pregnant women in Amazonas State, Brazil. Epidemiol Serv Saude 2003; 12:155-164.

25. Alcalde R, Melo FL, Nishiya A, Ferreira SC, Langhi Jr MDL, Fernandes SS, et al. Distribution of hepatitis B virus genotypes and viral load levels in Brazilian chronically infected patients in São Paulo city. Rev Inst Med Trop Sao Paulo 2009; 51:269-272.

26. Nita ME, Gaburo Jr N, Cheinquer H, L'Italien G, Affonso AES, Matilla P, et al. Patterns of viral load in chronic hepatitis B patients in Brazil and their association with ALT levels and HBeAg status. Ann Hepatol 2009; 8:1-7.
27. Altinbas A, Aktas B, Basar O, Yüksel O, Ekiz F, Yilmaz B, et al. Is there an association between the measurement of qualitative HBsAg and virologic response in chronic HBV infection? Ann Hepatol 2012; 11:320-325.

28. Chu MC, Sheen IS, Lin SM, Liaw YF. Sex difference in chronic hepatitis $B$ virus infection: studies of serum $\mathrm{HBeAg}$ and alanine aminotransferase levels in 10,431 asymptomatic Chinese HBsAg carriers. Clin Infect Dis 1993; 16:709-713.

29. Tonetto PA, Gonçalves NS, Fais VC, Vigani AG, Gonçales ES, Feltrin $\mathrm{A}$, et al. Hepatitis B virus: molecular genotypes and $\mathrm{HBeAg}$ serological status among HBV-infected patients in the southeast of Brazil. BMC Infect Dis 2009; 9:149.

30. Becker CE, Mattos AA, Bogo MR, Branco F, Sitnik R, Kretzamnn NA. Genotyping of hepatitis B virus in a cohort of patients evaluated in a hospital of Porto Alegre, south of Brazil. Arq Gastroenterol 2010; 47: 13-17.

31. Panduro A, Meléndez GE, Fierro NA, Madrigal BR, Zepeda-Carrillo EA, Román S. Epidemiology of viral hepatitis in Mexico. Salud Publica Mex 2011; 53:37-45.

32. Pereira MA, Ortiz-Agostinho CL, Nishitokukado I, Sato MN, Damião AO, Alencar ML, et al. Prevalence of celiac disease in an urban area of Brazil with predominantly European ancestry. World J Gastroenterol 2006; 12:6546-6550.

33. Gandolfi R, Prateso R, Córdoba JC, Tauil PL, Gasparin M, Catassi C. Prevalence of celiac disease among blood donors in Brazil. Am J Gastroenterol 2000; 95:689-692.

34. Moura ACA, Castro-Antunes M, Lima AM, Nobre JMM, Motta MEFA, Silva GAP. Serological triage for celiac disease in adolescents and young adults attending university. Rev Bras Saude Mater Infant 2012; 12: 121-126.

35. Melo SB, Fernandes MI, Peres LC, Troncon LE, Galvão LC. Prevalence and demographic characteristics of celiac disease among blood donors in Ribeirão Preto, State of São Paulo, Brazil. Dig Dis Sci 2006; 51:10201025.

36. Castro-Antunes MM, Magalhães R, Nobre JM, Duarte BP, Silva GAP. Celiac disease in first-degree relatives of patients. J Pediatr 2010; 85: 331-336.

37. Alencar ML, Ortiz-Agostinho CL, Nishitokukado I, Damião AOMC, Abrantes-Lemos CP, Leite AZA, et al. Prevalence ofceliac disease among blood donors in São Paulo - the most populated city in Brazil. Clinics 2012; 67: 1013-1018.

38. Rampertab SD, Pooran N, Brar P, Singh P, Green PHR. Trends in the presentation of celiac disease. Am J Med 2006; 119:355.e9-355.e14.

39. Silva CMS, Souza MVL. Autoimmune hypothyroidism nonresponsive to high doses of levothyroxine and severe hypocalcemia. Arq Bras Endocrinol Metab 2005; 49:599-603.

40. Mantan M, Dhingra D, Sethitais GR. Unusual presentation of celiac disease presenting with renal complications. Indian J Pediatr 2012; 79:530-531.

41. Sima H, Hekmatdoost A, Ghaziani T, Alavian SM, Mashavekh A, Zali MR. The prevalence of celiac autoantibodies in hepatitis patients. Iran J Allergy Asthma Immunol 2010; 9:157-162.

42. Scaraveli NG, Passoas AM, Voigt AR, Livramento A, Tonial G, Treitinger A, et al. Seroprevalence of hepatitis B and hepatitis C markers in adolescents in Southern Brazil. Cad Saude Publica 2011; 27:753-758.

43. Nejad MR, Rostami K, Zali MR. Hepatitis B vaccination reliability in celiac disease. Hepat Mon 2011; 11:59759-59768.

44. Ertekin V, Tosun SM, Selimoglu MA. Is there need for a new hepatitis B vaccine schedule for children with celiac disease? Hepat Mon 2011; 11:634-647.

45. Franca R, Diniz-Santos DR, May DS, Saback TL, Silva LR. Alterações hepáticas na doença celíaca. R Ci Med Biol 2006; 5:275-280. 